\title{
Calendar of Events 2014 Overview
}

\section{February 05-06, 2014}

Radiopharmaceuticals - Quality, Safety and GMP Requirements Regulatory Developments and Practicle Experiences on GMP Implementation

Imperial Riding School — Renaissance Hotel

Ungargasse 60

Vienna, AUSTRIA

\section{February 10-14, 2014}

ICTR-PHE 2014

A conference that brings together the International Conference on Translational Research in Radio-Oncology and Physics for Health in Europe

Centre International de Conferences de Geneve (CICG) International Conference Centre Geneva 17, rue de Varembé CH-1211 Geneva 2, SWITZERLAND

\section{February 17-21, 2014}

$3^{\text {rd }}$ Tübingen PET/MR Workshop

4,5 day interdisciplinary workshop on PET/MR divided

in Block I (hands-on) and Block II (presentations by

internationally renowned experts)

University Department of Radiology

Hoppe-Seyler-Str. 3

72076 Tübingen, GERMANY

\section{February 19, 2014}

Radiation Protection in Nuclear Medicine

This conference will provide updates on past issues as well as covering a range of new and current topics

Austin Court, 80 Cambridge Street

Birmingham, B1 2NP, UNITED KINGDOM

\section{February 24, 2014}

$3^{\text {rd }}$ Annual SPECT/CT symposium: Current status and future directions of SPECT/CT imaging

Royal Society of Medicine

London, UNITED KINGDOM

\section{March 10-12, 2014}

Implementation of V/P Spect according to European guidelines Skåne University Hospital

Lund, SWEDEN
March 29-30, 2014

Nuclear Medicine Satellite Course "Diamond"

Davos, SWITZERLAND

\section{March 31, 2014-April 01, 2014}

$3^{\text {rd }}$ European Conference on Clinical Neuroimaging (ECCN 2014) Lille, FRANCE

\section{April 02-04, 2014}

Beyond FDG: International Symposium on PET tracers in Oncology

This International Symposium provides a state of the art of the second generation of PET tracers

University Medical Center Groningen

Groningen, NETHERLANDS

April 09-11, 2014

Positron Emission Tomography (PET):

Technology and Application

Kings College London - Guy's Campus(London Bridge)

Gordon Museum

Hodgkin's Building

Guy's Hospital

St. Thomas's Street

London, UNITED KINGDOM

April 23-26, 2014

$3^{\text {rd }}$ Balkan Congress of Nuclear Medicine

Present and Future in Nuclear Medicine

JW Marriott Grand Hotel

Bucharest, ROMANIA

April 24-27, 2014

ESRR'14-17 $7^{\text {th }}$ European Symposium on Radiopharmacy and Radiopharmaceuticals

Campus Universitario

31009 Pamplona

Navarra, SPAIN

April 25-28, 2014

$44^{\text {th }}$ Annual Scientific Meeting of the Australian and New Zealand Society of Nuclear Medicine

The theme of the meeting is "A Fusion of Ideas, Modalities, and Disciplines", with an exciting program emphasising the place of Nuclear Medicine in the multi-disciplinary practice of medicine Adelaide Convention Centre Adelaide, SOUTH AUSTRALIA 


\section{May 03-07, 2014}

$16^{\text {th }}$ European Congress of Endocrinology

Wrocław, POLAND

\section{May 05-07, 2014}

$11^{\text {th }}$ Annual ENETS (European Neuroendocrine Tumor Society) Conference

Barcelona, SPAIN

\section{May 09-12, 2014}

$8^{\text {th }}$ International Congress of the Croatian Society of Nuclear Medicine

Šibenik, CROATIA

\section{May 11-14, 2014}

British Nuclear Medicine Society Annual Spring Meeting 2014 The BNMS welcomes you to join our $42^{\text {nd }}$ Annual Spring Meeting in Harrogate International Centre UNITED KINGDOM

\section{May 12-14, 2014}

Odense Spring Meeting 2014

Molecluar Imaging: Solution to Tomorrow's Health Care?

Radisson Blu H.C. Andersen Hotel

Claus Bergs Gade 7

5000 Odense C, DENMARK

\section{May 22-25, 2014}

$8^{\text {th }}$ European Symposium On Paediatric Nuclear Medicine Park Hotel San Jorge

Platja D'aro — Girona, SPAIN

\section{May 23-24, 2014}

EANM Learning Course on Trends in PET — Methodologies EANM Educational Facility

European Association of Nuclear Medicine (EANM)

Hollandstrasse 14/Mezzanine

1020 Vienna, AUSTRIA

\author{
May 28-30, 2014 \\ $14^{\text {th }}$ Scientific Congress of PTMN \\ (Polish Society of Nuclear Medicine) \\ Fair-exhibition Centre "Targi Lublin S.A." \\ Lublin, POLAND
}

\section{May 30-31, 2014}

I International Conference of Nuclear Medicine Technologies \& X Seminar of Nuclear Medicine from Lisbon School of Health Technology

Auditorium of Lisbon School of Health Technology

Escola Superior de Tecnologia da Saúde de Lisboa

(Lisbon School of Health Technology)

Lisbon, PORTUGAL

\section{May 30-June 02, 2014}

$2^{\text {nd }}$ International Conference on Radiation Protection in Medicine

Riviera Holiday Club

Varna, BULGARIA

June 07-11, 2014

SNMMI 2014 Annual Meeting

St. Louis Convention Center

701 Convention Plaza

St. Louis, MO 63101, USA

\section{June 21-24, 2014}

ICE/ENDO 2014

Organization: International Congress of Endocrinology,

Endocrine Society

Chicago, Illinois, USA

July 10-12, 2014

EFOMP School for Medical Physics Experts (Nuclear Medicine) "Advanced Kinetic Modeling and Parametric Methods. Advanced SPECT and PET Applications in Cardiology, Neurology and Oncology" Prague, CZECH REPUBLIC 